УДК 338.244(571.53)

\title{
The Bratsko-Ust-Ilimsk Complex \\ as a Model of Soviet Planned Economy
}

\author{
Grigory A. Tsykunov* \\ Baikal State University of Economics and Law \\ 11 Lenin Str., Irkutsk, 664003, Russia
}

Received 24.08.2014, received in revised form 05.09.2014, accepted 08.10.2014

The article explores the historical experience of creation of the Bratsko-Ust-Ilimsk territorial production complex (TPC) as one of the forms of territorial organization of national economy characteristic of planned economy. Economic advantages of the TPC are aimed at the development of new territories, specifics of their functioning in the conditions of the market relations.

Keywords: territorial production complex, planned economy, infrastructure, complex development.

Research area: History.

The Soviet models of economic development of the new territories that have become property of history still draw attention of researchers in various scientific areas. Within several decades in the uninhabited areas of Siberia and the Far East there were large industrial centres with mining and processing industry, transport systems, city agglomerations. Modern Russia mainly lives at the expense of the industrial potential of the planned economy. However, the next exploitation of natural resources in Northern and Far East regions of the country, with their severe climatic conditions, impassability and unsettled territories will be required in the near future. Therefore, it would be unjustified not to use the Soviet practice of the territorial organization of productive forces.

In the conditions of the planned economy, industrial development of East regions of the country took place within the long-term state programs that had national value. Implementation of the Angaro-Eniseysk project, which became the stepping stone of large-scale development of resources in Krasnoyarsk and Irkutsk regions, was one of such Siberian programs. Broad hydropower construction on the Angara and the Yenisei Rivers was the basis for formation of the whole system of the territorial and production complexes (TPC): Bratsko-Ust-Ilimsk (BITPC), Sayansk, Kansk and Achinsk. The theoretical foundation of economic division into districts in the form of the TPC was established by prominent Soviet scientists I.G. Alexandrov, N.N. Baranovsky, N.N. Kolosovsky. The main advantage of the TPCs was their unique opportunity to involve in the economic circulation of natural resources with the least material and financial inputs, first of all, in areas of new economic development.

In the territory of the former Soviet Union there was formation and development of 15

(c) Siberian Federal University. All rights reserved

* Corresponding author E-mail address: tsykunov-ga@isea.ru 
territorial and production complexes. With each fifth anniversary they played an escalating role in the national economy of the country, turned into the powerful centres of production and raw materials processing. Comprehensive programs of development were developed for some complexes. However, collapse of the USSR and the subsequent transition from the planned economy to the market relations interrupted the implementation of long-term plans of the social and economic development of certain territories of Siberia, including TPCs. At the same time results reached during years of the Soviet practice were impressing.

One of the few TPCs, formation of which was generally complete, was the Bratsko-UstIlimsk TPC. It was the place where scientific ideas of TPC were approved in full scale; there was a difficult search of ways of an integrated approach to the organization of economic life of the territory. The Bratsko-Ust-Ilimsk complex was predetermined by the richest natural resources, this area possessed hydropower, minerals, forest. However, unique hydro-energy resources of the Angara River were considered as the main advantage of this territory for a long time. Other values of the Middle Angarsk region were huge stocks of forest resources, which created favourable conditions for placement of a powerful complex of mechanical and chemical processing of wood. In the territory of a complex there was the Angaro-Ilimsk iron-ore pool that was one of the largest in Siberia. With this type of fuel explored reserves of coal could provide not only industrial hubs of the TPC, but also regions of the Western site of BAM. Within the region there were reconnoitred stocks of gas used at one of the thermal stations of Bratsk.

Formation of the Bratsko-Ust-Ilimsk complex began with the hydroelectric power station construction, the decision about which was made in 1954. Special department Bratskgesstroy which was entrusted with the construction of the Brotherly water-engineering system was created at the same time. Again created organization was headed by I.I. Naymushin, ex-director of the construction of the Kamsk hydroelectric power plant. In 1956, a special resolution of the Council of ministers of the USSR created a production base of construction of Bratsk hydroelectric power plant. The construction of this water-engineering system was highlighted by record achievements in domestic hydropower engineering. First of all, it concerned speed of construction and commissioning of units of the plant. The period between the beginning of construction and startup of the first units took six years, and between start-up of the first and the last units of the plant it was six years. As a comparison, in construction of the Sayano-Shushensk hydroelectric power station the similar periods were 16 and 12 years. In 1967, the state commission accepted the Bratsk hydroelectric power station in operation with a "perfect" assessment.

The Bratsk hydroelectric power station became a peculiar scientific and technical laboratory for verification of scientific and design decisions at creation of the power equipment for Krasnoyarsk and Ust-Ilimsk hydroelectric power stations, Aswan hydroelectric power station in Egypt. For studying the best practices of exploitation of stations the employees of other power plants of the country came, as well as from Egypt, India, Pakistan, Yugoslavia and Romania.

Around the Bratsk hydroelectric power station there was the main industrial hub where besides the powerful water-engineering system was created the central base of the industry, largest in the branches timber processing complex and aluminium plant. A hydroelectric power station and a timber processing complex constructed on a compensation basis with participation of the former member countries of the Comecon 
(Council for Mutual Economic Assistance) worked at the Ust-Ilimsk industrial hub. The third industrial hub was created on the basis of the Korshunovsk iron-ore field where mining and processing integrated works and the city of Zheleznogorsk-Ylym were situated. By the end of 1970 The Bratsko-Ust-Ilimsk TPC provided release of the third part of the industrial output of the Irkutsk region.

Processes of formation of the Siberian TPC, firstly Bratsk and Ust-Ilimsk, was attentively observed from abroad. One of the manifestations of this interest was the conference devoted to implementation of the large regional program in the USSR by the example of the BratskoUst-Ilimsk TPC, held in 1976 in Vienna by the International Institute for Applied System Analysis. Experience of development of the Siberian complex in comparison with a control system of the powerful complex created in the USA in a valley of the river of Tennessee was highly appreciated by the experts. This fact confirms expediency of a scientific study of difficult processes of the social and economic reorganization of the low-rendered habitable areas in whatever parts of the world they were.

As shown by the BITPC experience, the key to success of development of new regions is a scientific and project preparation of the territory. In the 1920s a complex research of the Angara was carried out, the result of which was the development of the first option of hydropower construction and placement of an industrial complex of the interconnected enterprises. In 1934, development of the scheme of use of hydroenergy resources of the Angara, that has received the name of the project of Angarstroy, was finally completed. Results of the research and project works on the Angarsk problem were brought at post-war conferences on development of productive forces of the Irkutsk region in Eastern Siberia.
All courses of formation of the BITPC show that more than $80 \%$ of volume of capital construction for its territories was carried out by forces of the construction organization Bratskgesstroy [1, page 131]. Concentration of a versatile production base, design divisions, financial and other resources in a single pair of hands allowed to pursue a uniform construction policy in complex scales and to provide a faster construction of industrial and civil facilities (compared to other Areas of Siberia). Thus, a head organization was created on the basis of Bratskgesstroy, which defined the direction of all BITPC construction programs. None of the TPCs formed in the Soviet period had such opportunity. Continuity of construction collectives played an important role in economic development of new areas, which was visually confirmed by the practice of Bratskgesstroy. Highly skilled builders of the Bratsk hydroelectric power station became a core of again created staff of construction of the Ust-Ilimsk hydroelectric power station. After completion of the main works on the Ust-Ilimsk water-engineering system a considerable part of employees and engineering-technical workers waiting for broad expansion of construction of the Boguchansk hydroelectric power station was involved in a timber processing complex construction. Further the Ust-Ilimsk hydrobuilders began works on construction of the Telmamsk hydroelectric power station in a formed Bodaybinsk industrial hub.

Capacities and structure of Bratskgesstroy quite corresponded with the needs of the region. Moreover, a part of its capacities was intensively used by the Ministry of Energy of the USSR in construction of various objects in seven regions and areas of Russia. In 1987, Bratskgesstroy structurally consisted of 12 contract and 6 specialized construction divisions, 5 industrial enterprises, a design office, a base for inservice training, an economic school, and also 
a number of subcontract organizations. Total number of employees of construction divisions of Bratskgesstroy reached 72 thousand people [5, page 48]. For excellent performance of the state tasks in construction of power, industrial and civil facilities the staff of Bratskgesstroy was awarded by the Orders of Lenin and October revolution.

The territorial and production complex is considered as a set of steadily interconnected productions of various branches of the national economy located in the limited territory and providing rational use of natural resources and manpower on the basis of uniform production and social infrastructure. During formation of the BITPC a powerful industrial potential consisting of power making and energy-requiring branches was created. Large consumers of energy were the enterprises of aluminium, pulp, paper and other industries. High efficiency of the complex was reached due to the involvement in economic circulation of unique natural resources of the region and their complex use. The Bratsk and Ust-Ilimsk timber processing complexes had no complete cycle of processing of wood. For example, these large enterprises did not incorporate furniture production.

Another factor of efficiency of the BITPC was early development of capacities, increase in production at operating capacities over the established production standards. Development of new capacities of the complex was rather quick. By the time of acceptance of the Bratsk hydroelectric power station in continuous exploitation it developed 66 billion $\mathrm{kW} / \mathrm{h}$ of the electric power, which completely paid back the cost of construction and temporary operation. During construction due to reduction of volume of concrete, earthwork and technical improvement the cost of hydroelectric power station was reduced almost by $18 \%$ and its power increased by $28 \%$ [6, page 395]. Similar achievements were not known in any hydroelectric power station of the country. In January, 2010, the Bratsk hydroelectric power station produced a trillionth $\mathrm{kW} / \mathrm{h}$ having become the absolute champion on the whole Eurasian continent.

One of compound infrastructures of TPC was existence of the corresponding food base providing with food of the population living here. However, in the conditions of quickly increasing population of the BITPC agriculture of the region could not adapt to the changed conditions of the region. The acute shortage of farmlands was the main reason of slow rates of building of food production. As a result of creation of Angarsk reservoirs the most part of the developed fertile lands, the technical base, as well as the rendered habitable country settlements were put out of action. The total area of flooding in a zone of the Bratsk water-engineering system involved 167 thousand hectares with 67,8 thousands hectares of an arable land, in a zone of the Ust-Ilimsk waterengineering system - 21,3 thousands hectares and 12,3 thousands hectares of the well-known Ylym arable land [3, page 51]. The area of again developed lands was much less than that the area which got to a flooding zone. At the same time in the solution of a food problem of BITPC there were also positive moments to which it is necessary to refer production of agricultural products on an industrial basis. Experience of the hothouse and greenhouse combine of the state farm "Pursey" receiving heat and water of the Bratsk Forestry Complex showed high efficiency of the similar organization of agricultural production. More than a half of all the vegetables were made there from regional gross collecting, and the state farm surpassed many hothouse combines of RSFSR in productivity of cucumbers. Creation of subsidiary farms on the basis of the industrial enterprises, construction organizations and other establishments became another direction in the production of local food. A certain contribution to the solution of problems of providing products 
of the population of the region was intensive development of garden and garden cooperatives. In the number of gardeners per capita Bratsk won first place in the country.

Implementation of the Angarsk project and formation of the Bratsko-Ust-Ilimsk TPC demanded large-scale involvement of labor to the region. If in 1939 in the territory of the future complex the population was only 44.5 thousand people, in 1959 - already 155.7 thousand, in 1970 344.6 thousand, in 1981 - 504.1 thousand, and in 1991 - 581.2 thousand people. In the territory of the BITPC urban population was $84.5 \%$ out of the whole population in 1985 [4, page 43-44]. Population of the BITPC in many respects was defined by developments of labor collectives, their structure and replenishment sources. The latter had impact on the processes of formation of the population, its qualitative characteristics. Formation of labor collectives was one of the most difficult social and economic processes in the TPC territory. There various forms of completing of working collectives were used: reception on a place and on calls of human resources departments; organizational set; public appeal; in the direction of technical training colleges; set invalided solders. The greatest interest represents a public appeal which captured a mass movement of youth on a construction of the new industrial enterprises and the cities. The most part of youth came as a part of Komsomol groups. For fixing of workers there was established the increased regional coefficient of a salary and created conditions for professional growth.

In the conditions of formation and BITPC development the social sphere that defined one of the main directions - an increase of a standard of living of the population - had prime value. It depended on a number of economic, social and demographic and climatic factors. Intensive industrial development of the region caused rapid growth of population and city agglomerations.
Distinctive feature in development of the young cities of the TPC was a departmental approach to planning, financing and building. In these conditions each ministry placed own housingand-municipal, cultural and community objects near their enterprise. Nevertheless in the cities and settlements of the BITPC the necessary domestic conditions were created, improvements of housing differed by high level. So in the mid-1980s specific weight of the housing stock equipped with a water supply system made $92.8 \%$, sewerage $-90.6 \%$, central heating $-91.3 \%$, hot water supply $-81.9 \%$ [3, page 98]. It is necessary to recognize that development of a network of health care took slow rates because of belonging of medical institutions to various departments. On the other hand development of a network of improving establishments is impressing. In 1981, only in the city of Bratsk improving complexes, sanatoria and recreation facilities could accept annually about 20 thousand people that allowed the organization of good rest and treatment both short and long-term without leaving out of the TPC limits.

Thus, in the period of the planned economy formation and development of the TPC provided an economic effect at development of new areas with rich natural resources and extreme conditions. The problem of settling of these regions that was promoted by the state policy on resettlement stimulation to Siberia was solved at the same time.

Transition to the market was radically reflected in the TPC functioning. Having lost plan targets they faced lack of demand for the production turned into chaotic associations of the enterprises with low competitiveness. All this in some scale affected on functioning of the Bratsko-Ust-Ilimsk complex. In the cities of Bratsk, Ust-Ilimsk, Zheleznogorsk the large enterprises were city-forming, around which all city spheres became isolated. With arrival of 
the market relations, the model of city-forming created a number of serious problems, from which the main one was direct dependence of life support of the cities and settlements on an economic condition of the enterprises. As a rule, the financial and industrial groups that have come to the city-forming enterprises did not hurry to invest money in further development of production. Refusal of the maintenance of the departmental social sphere became another direction of commercialization. Their transfer to maintaining municipalities complicates account part of local budgets.

Economy restructuring, rash privatization led to a stop of the TPC large enterprises, created the most difficult social and economic situation in the cities. So, from the enterprises of the uniform Ust-Ilimsk timber processing complex during 1993 it was created 40 independent joint-stock companies. Until recently labour collectives connected by the general technology, power and engineering communications, material benefits were separated and went out of business. The stop of the city-forming enterprise turned back a social disaster for residents of Ust-Ilimsk who began to leave the city. From 1994 to 2006 the population of Ust-Ilimsk was reduced from 111.3 by 98.6 thousand people [2, page 39].

Liquidation of earlier effectively working enterprises and the organizations became the most serious consequences of market reforms. In the Soviet period the Bratsk plant of heating equipment was considered as one of the best in branch, carried a deserved rank of the enterprise of high culture of production. However in the new economic conditions, earlier demanded in the country and abroad production suddenly became unclaimed. The sad fate took the construction department of Bratskgesstroy the national property of Russia that has won an international recognition. The termination of financing of construction objects, refusal of the former target programs, and the followed process of privatization liquidated uniform structure and brought construction divisions to bankruptcy. Thousands of workers became unemployed; the powerful social sphere was liquidated. Liquidation of numerous collectives led to migratory outflow of the population. From 1991 till 2010 the population of the BratskoUst-Ilimsk complex was reduced from 581.7 thousands to 487.3 thousand people or by $16.2 \%$ [7, page 3-5].

In recent years in Russia the cluster theory is widely adopted. At similarity of definitions of the TPC made by the Soviet scientists to concept of a cluster, between them there are also fundamental differences. So, the concept of TPC is characteristic for a planned economy, the cluster - for the market. TPC are formed in areas of new economic development, clusters - in the old mastered regions. In this regard the approved experience of formation of TPC, by the example of Bratsko-Ust-Ilimsk, nevertheless, is suitable for modern Russian practice better.

\section{References}

1. Irkutsk region 70 years. Anniversary edition. Stat. Collection. Irkutsk, 2007, 272 p.

2. Tsykunov, G.A. The Angaro-Eniseysk TPC: problems and experience (historical aspect). G. A. Tsykunov. Irkutsk, 1991. 176 p.

3. Tsykunov, G.A. The Bratsko-Ust-Ilimsk complex: history, problems, prospects. Bratsk, 1995. $71 \mathrm{p}$.

4. Tsykunov, G.A. Farewell Bratskgesstroy. Irkutsk historical and economic year-book: 2004, G.A. Tsykunov. Irkutsk: BGUEP publishing house, 2004. 232 p. 
5. Tsykunov, G.A. Records of the Bratsk hydroelectric power station. Irkutsk historical and economic year-book: 2010, G. A. Tsykunov. Irkutsk: BGUEP publishing house, 2010. 640 p.

6. Population on the cities and areas. Stat. Bulletin. Irkutsk, 2010. $47 \mathrm{p}$.

7. Questions of formation of the Bratsko-Ust-Ilimsk TPC. Novosibirsk, 1977. 178 p.

\section{Братско-Усть-Илимский комплекс \\ как модель советской плановой экономики}

Г.А. Цыкунов

Байкальский государственный университет экономики и права

Россия, 664003, Иркутск, ул. Ленина, 11

Исследуется исторический опыт создания Братско-Усть-Илимского ТПК в качестве одной из форм территориальной организации народного хозяйства, характерной для плановой экономики. Экономические преимущества ТПК отмечены на развитие новых территорий, особенности их функционирования в условиях рыночных отношений.

Ключевые слова: территориальный производственный комплекс, плановая экономика, инфраструктура, комплексное развитие.

Научная специальность: 07.00.00 - исторические науки. 